\title{
PERCEPTIONS OF SECURITY CONTRIBUTING TO THE IMPLEMENTATION OF SECURE IS
}

\author{
Theodore TRYFONAS and Evangelos KIOUNTOUZIS \\ Dept. of Informatics, Athens University of Economics and Business \\ 76 Patission Street, GR-10434, Athens, GREECE \\ \{tryfonas,eak\}@aueb.gr
}

Key words: Information systems implementation, IS security integration, Security perceptions, Metaphors.

\begin{abstract}
Contemporary information systems (IS) development within organisations involves multiple interconnected systems, a variety of development practices and also outsources responsibilities to third parties. It hence introduces new threats, new vulnerabilities and in consequence new security problems for the IS. In this paper we propose a theoretical framework to facilitate the implementation of secure IS into this contemporary, particularly complex, organisational environment. We start our study by examining organisational and systems development issues, such as the involved stakeholders and their security requirements. We then relate this theory to practice by identifying all those concepts that materialise the stakeholders' security understanding to specific security objectives and the tools in which they are manifested. Finally, we inspect various published cases in order to examine the use of these tools within organisations, so as to realise our theoretical design and prescribe its further use.
\end{abstract}

\section{INTRODUCTION}

The information systems (IS) literature has little so far to present in terms of frameworks, methodologies or techniques that consistently integrate

The authors would like to thank the Hellenic Ministry of Development for its kind support in this research work, through the research programme YPER97.

The original version of this chapter was revised: The copyright line was incorrect. This has been corrected. The Erratum to this chapter is available at DOI: 10.1007/978-0-387-35691-4_52 
security with IS development (ISD). Researches however have been arguing that this is the most appropriate way of introducing security in the complex context of an IS for some time now (e.g. Baskerville, 1993). It seems that there exist significant barriers for such a task, as there are factors that lead practitioners first to implement a system and then to secure it. This can happen because during its development phase a system is not fully known in terms of its final attributes, hence the difficulty in protecting it. In addition, prior to its use a system's adding value might not be completely clear to its stakeholders; therefore valuation of its assets might not be accurate.

Most of the researchers who approach the problem propose ways of incorporating security within particular development steps, e.g. requirements collection, data modelling etc. (Siponen, 2001). Such approaches however are usually proprietary for specific development methodologies, techniques or tools. This is a problem though, as practitioners tend to customise or mix a wide range of ISD methodologies, techniques and tools, of the plethora being offered today (Fitzgerald, 1998).

Thus, the existing approaches for embedded IS security restrict the ability of the developers to use the development practices they prefer. This is a significant obstacle in the design of a methodological construct to achieve security integration with development. Siponen and Baskerville (2001) try to resolve this conflict by moving their proposed theoretical construct in the level of meta-methodology. They describe foundational concepts that could be embedded in any development methodology and facilitate the security design within the system design process. Their approach implies that the agent of the IS security enrichment is the developer, responsible for the design and the implementation of the system. It is possible however to create a theoretical construct to guide, in a similar manner, the security practitioner involved in the process (consultant, risk analyst etc.).

In this paper we try to produce a framework to assist the security expert in the selection of the appropriate security practices and tools, given an organisational context and a case of a system under development. In section two we present our research approach. Section three introduces theoretical aspects important for IS security (such as the stakeholders, the development approaches etc.) and also extends our reasoning based on an analysis of empirical data. Section four presents our proposed framework, whilst section five concludes with a summarising discussion.

\section{RESEARCH APPROACH}

IS researchers have pinpointed many important factors facilitating the development of secure systems. Those factors are a mixture of technical, 
social and managerial concerns, all important for building systems that can meet the security expectations of the involved parties. As it largely addresses 'soft' factors apart from the technicalities, the research approach should be capable of interacting between the two. For such an inquiry it is rather appropriate to use empirical observation and interpretive research (Walsham, 1995).

Following the research principles of analysis of empirical data and of the interpretive approach we develop a theoretical construct to facilitate the integration of security practices and tools to IS implementation. We inspect secondary empirical data, as it appears in published case studies concerned with IS securing projects or computer abuse cases. We then employ stakeholder analysis, IS theory, with regard to ISD approaches and the tools to secure information systems, and finally metaphors, as theoretical constructs in order to consolidate our analysis findings. Therefore we initially observe the related theory elements emerging through the empirical data and eventually we try to theorise those findings that can be generalised.

\section{REFLECTIONS ON THEORY AND PRACTICE}

\subsection{Theoretical contextualisation of systems security}

Several researchers have employed metaphors as mental models in order to understand the organisation and the phenomena within it (Morgan, 1997). There is a variation of the used ones, but they could all be summarised in three major categories: those describing the organisation as a (mindless) machine, those that describe it as an (individually minded) organism or a part of it, and those that describe it as a social (collectively minded) system.

It is interesting to note that the implicit adoption of any of such an understanding leads the analysts to focus on qualities that emerge from it (Walsham, 1991). This holds true for the security experts as well; in the machine analogy for example, as the workforce, material and informational resources are treated as interchangeable parts, it is important for the practitioner to locate, evaluate and assure those elements, in other words the organisational assets.

In a similar manner, the living analogy emphasises on the system's processes, because it is difficult to locate discrete assets due to the systems' emergence property (for example in an organism a 'leg' is not separable nor interchangeable as such, thus it is difficult to be treated as a concrete element, but 'health' can be treated as such). We believe that this observation is crucial for the subject matter of our study as such concepts imply what is important for the organisation, hence what needs protection. 
Tryfonas and Kiountouzis (2002) use this as a starting point to draw comments on a theoretical discussion about important factors affecting the integration of systems development with systems security. The major factors they identified were:

- The expert's perception of the organisation.

- The stakeholders involved plus their expectations about the outcomes of the securing venture.

- The concept(s) that mediate those expectations and communicate them to the experts.

We think that this last issue is particularly important. Further illustration of the way those concepts mediate the communication between organisational stakeholders and security experts and become objects of discourse is therefore necessary.

\subsection{Organisational constructs facilitating an IS view on the practice of systems security}

The stakeholders' implicit understanding of IS security is realised as explicit security requirements through supportive concepts that mediate the communication between them and the security experts. Those elements embody the security objectives and become objects of discourse between the stakeholders and the experts. The most popular of them seem to be the concepts of the asset, the process and the stake of an individual or a group of people. We claim here that each such concept can be also a driver for the security methods and tools to be used.

\subsubsection{Emerging approaches}

As organisations operate in an uncontrolled environment, elements that, for whatever reason, could deviate from their expected state become a major issue of concern. Such a potential deviation can be perceived through the concept of accidental or deliberate risk, interpreted as the uncertainty that organisational elements might get exposed to, usually described in quantified and measurable terms.

In the following paragraphs we present a rudimentary classification of security approaches based on the organisational element of concern they focus on and discuss them in further detail.

\section{Asset-based approach}

As information adds value through its processing to the organisation, it is considered to be an organisational asset. It lives in the form of data that are accessed through information technology (IT) facilities. Potential threats against those data and facilities can be identified and their impact can be 
'calculated' in terms of cost. This leads to the association between assets, threats and impacts. This is an approach widely employed in the field of IS security, influenced by a resource-based view of the organisation (e.g. Finne, 1998; Baskerville, 1993 etc.). An example of a risk analysis (RA) method utilising the concept of the asset, giving particular emphasis in asset identification and valuation, is the CCTA Risk Analysis and Management Method (CRAMM).

\section{Process-based approach}

Various researchers have signified the importance of process-modelling for the understanding of the organisation. For security scholars, a process model facilitates audit and control because it makes it easier to focus on points that could destabilise the system due to accidental or deliberate incidents. Researchers observed that a number of security issues arise from mistakes, omissions or failures within the systems development process (e.g. Wood \& Snow, 1995; Anderson, 1993). The result is a defected product/system that its defects could be abused, so as to compromise an information system. Other researchers proposed ways of inspecting and evaluating process security (Eloff \& von Solms, 2000) as a means to increase the assurance of a system.

\section{Stake-driven approaches}

Stake-driven approaches emerge in order to cope with the 'softer' factors (ethics, legislation, training, familiarization, user satisfaction etc.) involving individuals or groups of individuals that affect or are affected by the system.

We can identify two different streams:

- The stakeholder approach, where the involved individuals and their interactions with the system are identified and studied, for example including users' security responsibilities in job descriptions, concerns for human involvement etc. (e.g. Backhouse \& Dhillon, 1996). And

- The systemic approach, where the involved parties are described in terms of groups, institutions or other organisational formations ('systems') that socio-politically interact (e.g. Hitchings, 1995b).

Ideally, the identified stakeholders shall pinpoint themselves the organisational assets and processes and the risks against them. Such systemic and largely participatory approaches need however to be guided by skilled analysts that can facilitate the entire process. In addition, the involved users of the IS must have a significant level of awareness, motivation and willingness to partake in this venture, which prerequisites a substantial effort in training and related preparation. 


\section{Other approaches}

A number of other approaches are currently under research, as all previous approaches alone cannot ensure the secure state of a system under inspection. Such approaches introduce new organisational concepts that can be exploited and produce tools for embedding security into a system. There is for example the concept of the 'transaction' that could be utilised (Smith \& Eloff, 2001). Rules can be defined per identified type of transaction and monitored in any transaction instance.

Another concept is that of the 'trust' between components (e.g. Chadwick \& Basden, 2001 etc.). When properly quantified, it could be assigned as an attribute to different interoperable components and regulate their interaction. However the quantification of trust is still an obstacle for this approach, as it is very difficult to design globally accepted formal trust models.

As such approaches are currently under research, we shall not include those concepts (transaction, trust etc.) in our framework, taking into consideration only the approaches that have been rigidly exploited throughout literature and practice.

\subsubsection{Tools in use}

In the following Table 1 we have summarised the discussion on the theoretical constructs that introduce security in the IS and their associated tools.

Table 1: Theoretical constructs used to introduce security to the IS.

\begin{tabular}{|c|c|c|c|c|}
\hline & Principal construct & Approach & $\begin{array}{l}\text { Example } \\
\text { practices\&tools }\end{array}$ & $\begin{array}{l}\text { Example } \\
\text { references }\end{array}$ \\
\hline \multirow{5}{*}{ 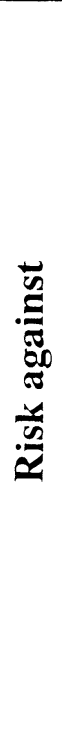 } & Asset & Asset-based & $\begin{array}{l}\text { RA, baseline } \\
\text { controls, best } \\
\text { practices }\end{array}$ & $\begin{array}{l}\text { Baskerville, } \\
\text { 1993; Finne, } \\
1998\end{array}$ \\
\hline & Process & Process-based & $\begin{array}{l}\text { Assurance, standards, } \\
\text { audit, contracts, } \\
\text { insurance, business } \\
\text { continuity }\end{array}$ & $\begin{array}{l}\text { Eloff \& von } \\
\text { Solms, 2000; } \\
\text { Wood \& Snow, } \\
\text { 1995; Anderson, } \\
1993\end{array}$ \\
\hline & $\begin{array}{l}\text { Stake of the - } \\
\text { - Individual }\end{array}$ & $\begin{array}{l}\text { Stake-driven } \\
\text { Stakeholders }\end{array}$ & $\begin{array}{l}\text { Training, security } \\
\text { responsibilities in job } \\
\text { descriptions, chains } \\
\text { of command, job } \\
\text { satisfaction }\end{array}$ & $\begin{array}{l}\text { Backhouse \& } \\
\text { Dhillon, } 1996\end{array}$ \\
\hline & - Group & Systemic & $\begin{array}{l}\text { General awareness, } \\
\text { ethics, } \\
\text { legal/regulatory } \\
\text { frameworks }\end{array}$ & Hitchings, $1995 \mathrm{~b}$ \\
\hline & Trust, Transaction etc. & $\begin{array}{l}\text { Other (under } \\
\text { research) }\end{array}$ & $\begin{array}{l}\text { Digital certificates, } \\
\text { fuzzy logic }\end{array}$ & $\begin{array}{l}\text { Chadwick \& } \\
\text { Basden, 2001; } \\
\text { Smith \& Eloff, } \\
2001\end{array}$ \\
\hline
\end{tabular}


The tools used to secure a system come to a variety of platforms and applications and could assist methods and techniques used anywhere within the development lifecycle. Hence it seems that concepts employed to introduce IS security to the organisation, can imply suitable practices to be used to secure its IS. As we discussed previously, most of them depend on an organisational concept that introduces the idea of security within the organisation. RA methods and assisting tools, IT security standards, access control mechanisms, data encryption facilities, biometrics etc. are all based on concepts such as assets, processes, responsibilities etc.

\subsection{Reflections on practice: Analysis of published cases}

In Table 2 we present the selected cases from the literature that we will investigate in order to extract feedback and facilitate our theoretical design. The sample we use is profiled in terms of the organisational context, the IS/IT infrastructure and its development approach, the study's objective, the security tool used and the formal project outcomes. The inspected cases concern both private and public sector organisations of a variant size.

In Table 3 we present further outcomes of our data analysis, discussing issues that are not directly quoted from the actual articles' text, but rather derived against the theoretical parameters we have discussed elsewhere in this paper. As the lengthy, detailed per-case analysis is beyond the objective of this research paper, we shall only discuss in this section summarising points that we think are important.

Our primary observation is that the empirical data verify the constructs we have identified as mediating the introduction of IS security into the organisational environment. Risks, assets, processes, stakes, are all used to highlight security problems and design solutions in each case.

The interesting outcome here is the association of those with the authors' (explicitly or implicitly) adopted organisational perception. For example risks and assets are usually used when the organisational perception is mechanistic. On the other hand assets and processes are concepts emerging through the biological metaphor, whereas processes and their involved stakeholders, or systems in general, emerge when the environment is explored through societal metaphorical mechanisms.

The empirical data also highlight the fact we draw in Table 1, that the 'security-facilitating' concept determines the nature of the securing method/tool to be used for the project. For example, the use of RA presupposes an emphasis given on the data viewed as organisational assets, or that auditing approaches requires particular understanding of the business processes. 
Table 2: A profile of the empirical data investigated.

\begin{tabular}{|c|c|c|c|c|c|}
\hline Cuse & $\begin{array}{l}\text { Organisational } \\
\text { rontext }\end{array}$ & Study's objective & $\begin{array}{l}\text { IS/IT } \\
\text { inficastructure } \\
\text { \& development }\end{array}$ & $\begin{array}{l}\text { Security } \\
\text { tool used }\end{array}$ & $\begin{array}{l}\text { Project } \\
\text { outcome }\end{array}$ \\
\hline $\begin{array}{l}\text { Frosdick } \\
\& \text { Odell, } \\
1996\end{array}$ & $\begin{array}{l}\text { England and } \\
\text { Wales Police }\end{array}$ & $\begin{array}{l}\text { To describe } \\
\text { Police's IS-related } \\
\text { risk management } \\
\text { standard in England } \\
\text { and Wales }\end{array}$ & $\begin{array}{l}\text { Proprietary, } \\
\text { loosely } \\
\text { coupled }\end{array}$ & $\begin{array}{l}\text { Risk analysis } \\
\& \\
\text { management }\end{array}$ & $\begin{array}{l}\text { National Policy } \\
\text { for IS/IT risk } \\
\text { management }\end{array}$ \\
\hline $\begin{array}{l}\text { Dhillon \& } \\
\text { Moores, } \\
2001\end{array}$ & $\begin{array}{l}\text { Stock exchange } \\
\text { (US) }\end{array}$ & $\begin{array}{l}\text { To draw theoretical } \\
\text { arguments on why } \\
\text { the IS-related risk } \\
\text { can come from } \\
\text { 'inside' }\end{array}$ & $\begin{array}{l}\text { Product-based } \\
\text { or component- } \\
\text { based, } \\
\text { centralised }\end{array}$ & $\begin{array}{l}\text { Law } \\
\text { enforcement }\end{array}$ & $n / a$ \\
\hline $\begin{array}{l}\text { Liechtenstein, } \\
1996\end{array}$ & Travel (AU) & $\begin{array}{l}\text { To draw theoretical } \\
\text { arguments on the } \\
\text { selection of a risk } \\
\text { assessment method }\end{array}$ & $\begin{array}{l}\text { Component- } \\
\text { based, } \\
\text { centralised }\end{array}$ & $\begin{array}{l}\text { Baseline } \\
\text { protection }\end{array}$ & $\begin{array}{l}\text { Baseline controls } \\
\text { implementation }\end{array}$ \\
\hline $\begin{array}{l}\text { Spurling, } \\
1995\end{array}$ & $\begin{array}{l}\text { Heavy industry } \\
\text { (AU) }\end{array}$ & $\begin{array}{l}\text { To propose } \\
\text { guidelines for } \\
\text { security awareness }\end{array}$ & $\begin{array}{l}\text { Product- } \\
\text { based, } \\
\text { centralised }\end{array}$ & $\begin{array}{l}\text { Security } \\
\text { awareness }\end{array}$ & $\begin{array}{l}\text { Organisational } \\
\text { change }\end{array}$ \\
\hline $\begin{array}{l}\text { Muir, } \\
1997\end{array}$ & $\begin{array}{l}\text { Education \& } \\
\text { research - } \\
\text { Library (US) }\end{array}$ & $\begin{array}{l}\text { To propose actions } \\
\text { against student } \\
\text { hackers }\end{array}$ & $\begin{array}{l}\text { Component- } \\
\text { based, } \\
\text { centralised }\end{array}$ & $\begin{array}{l}\text { Legal actions, } \\
\text { code of } \\
\text { student } \\
\text { conduct }\end{array}$ & $\begin{array}{l}\text { Organisational } \\
\text { change }\end{array}$ \\
\hline $\begin{array}{l}\text { Spinellis } \\
\text { et al., } \\
1999\end{array}$ & $\begin{array}{l}\text { Small } \\
\text { business/Home- } \\
\text { Office (GR) }\end{array}$ & $\begin{array}{l}\text { To pinpoint the } \\
\text { surprisingly high- } \\
\text { risk exposure of the } \\
\text { home-office } \\
\text { environment and } \\
\text { propose a best } \\
\text { practice }\end{array}$ & $\begin{array}{l}\text { Component- } \\
\text { based, } \\
\text { centralised }\end{array}$ & Risk analysis & $\begin{array}{l}\text { Baseline controls } \\
\text { recommendations }\end{array}$ \\
\hline
\end{tabular}

Table 3: Further data analysis.

\begin{tabular}{|l|l|l|l|l|}
\hline Case & $\begin{array}{l}\text { Driver(s) for security } \\
\text { requirements }\end{array}$ & $\begin{array}{l}\text { Metaphors } \\
\text { reflecting Authors' } \\
\text { organisational } \\
\text { perception }\end{array}$ & $\begin{array}{l}\text { Security seems to } \\
\text { be introduced } \\
\text { through }\end{array}$ & $\begin{array}{l}\text { Non-tangible } \\
\text { outcome(s) }\end{array}$ \\
\hline $\begin{array}{l}\text { Frosdick \& } \\
\text { Odell, 1996 }\end{array}$ & $\begin{array}{l}\text { Policing job } \\
\text { requirements }\end{array}$ & $\begin{array}{l}\text { Shifts from } \\
\text { mechanistic to } \\
\text { societal }\end{array}$ & Risk & $\mathrm{n} / \mathrm{a}$ \\
\hline $\begin{array}{l}\text { Dhillon \& } \\
\text { Moores, } \\
2001\end{array}$ & $\begin{array}{l}\text { Inefficiency of the } \\
\text { 'traditional' models } \\
\text { to explain breaks } \\
\text { from 'within' }\end{array}$ & Societal & Process & $\begin{array}{l}\text { Organisational } \\
\text { awareness }\end{array}$ \\
\hline $\begin{array}{l}\text { Liechtenstein, } \\
1996\end{array}$ & $\begin{array}{l}\text { Criticality of the } \\
\text { informational assets }\end{array}$ & Biological & Asset & n/a \\
\hline $\begin{array}{l}\text { Spurling, } \\
1995\end{array}$ & $\begin{array}{l}\text { Organisational } \\
\text { awareness }\end{array}$ & Biological & Process & Cultural change \\
\hline $\begin{array}{l}\text { Muir, } \\
1997\end{array}$ & $\begin{array}{l}\text { Organisational } \\
\text { awareness }\end{array}$ & Societal & $\begin{array}{l}\text { Stake of the } \\
\text { individual/Stakes } \\
\text { of interrelated } \\
\text { groups }\end{array}$ & $\begin{array}{l}\text { Organisational } \\
\text { change }\end{array}$ \\
\hline $\begin{array}{l}\text { Spinellis } \\
\text { et al., } \\
1999\end{array}$ & $\begin{array}{l}\text { The 'real' level of } \\
\text { risk }\end{array}$ & Biological & Process & $\begin{array}{l}\text { Increasing } \\
\text { awareness }\end{array}$ \\
\hline
\end{tabular}




\section{A FRAMEWORK FOR THE INTERPRETATION OF SECURITY UNDERSTANDING}

In the following paragraphs, we shall investigate how a consolidation of the theoretical factors discussed, such as the development approach, security requirements expressed by the involved stakeholders, the theoretical constructs mediating their realisation etc., can facilitate the implementation of secure systems. To achieve such a consolidation, we first grouped all inspected cases as per their corresponding understanding of organisation. Then we grounded each group on the analysis data, partly presented in Table 2 and Table 3. The result, as we see it in Table 4, is that specific patterns emerge, representing the basic interpretations of IS security perceptions. The latter can be of key importance for the security expert.

We argue that the organisational context dictates the security approach that is mostly appropriate. For example, it seems that in case the target organisation is perceived mechanistically and the information system is expected to retain certain behaviour and nature at any cost whatever the circumstances, formal, systematic tools are primarily suitable. On the other hand, systems that deal with a changing environment and must adapt to it, tend towards a mixture of systematic and systemic security approaches. Last but not least, systems characterised by their strong social character seem to tend to purely systemic approaches.

The perceptions of security that have emerged through our theory drawing and the analysis of empirical data are distinguished amongst the following (we have attributed a 'suitable' code title to each emerged category):

- "Fortress security", applicable whenever the organisational approach is mechanistic, the key concept is the risk against the system's valuable assets and the IS is usually built from scratch. Very common amongst governmental infrastructure systems, the military, the banking sector etc.

- "Shelter security", applicable when the organisational approach is mostly biological, the key concept is usually the risk against the system itself and/or the adding-value process or service (and its continuity) and the IS is usually built by combining multiple independent applications or by deploying enterprise-wide customisable cores. Representative for service provision-oriented civil authorities and private firms.

- "Web security", applicable for small home-office environments or research institutes, where the organisational approach is mostly societal, the key concept is the interacting uncontrollable elements or groups of elements and the IS are usually a combination of multiple components and services.

We think of the previous categories as of not being exclusively 'normative'. Concepts can span rows, especially those that neighbour. 
However, practice dictates that many times security failures occur because of a misunderstanding of the contextual security requirements, expressed through un-appropriate 'images' for the case, which leads to the adoption of un-appropriate security approaches and eventually results in the deployment of controls that are not suitable for this environment.

Table 4: Basic interpretations of security understanding.

\begin{tabular}{|c|c|c|c|c|c|}
\hline $\begin{array}{l}\text { Organisational } \\
\text { view }\end{array}$ & $\begin{array}{l}\text { Development } \\
\text { approach }\end{array}$ & $\begin{array}{l}\text { Security } \\
\text { focuses on } \\
\end{array}$ & $\begin{array}{l}\text { Suitable security } \\
\text { practises }\end{array}$ & $\begin{array}{l}\text { Metaphor in } \\
\text { use }\end{array}$ & $\begin{array}{l}\text { Example } \\
\text { cases }\end{array}$ \\
\hline Mechanistic & $\begin{array}{l}\text { Primarily } \\
\text { custom }\end{array}$ & $\begin{array}{l}\text { Asset / } \\
\text { Process }\end{array}$ & $\begin{array}{l}\text { - Risk analysis } \\
\text { - Security } \\
\text { requirements } \\
\text { analysis } \\
\text { - Codes of practice, } \\
\text { best practices }\end{array}$ & Fortress & $\begin{array}{l}\text { Frosdick \& } \\
\text { Odell, } \\
1996\end{array}$ \\
\hline Biological & $\begin{array}{l}\text { Primarily } \\
\text { configuration } \\
\text { of component- } \\
\text { based } \\
\text { (systems } \\
\text { integration) }\end{array}$ & $\begin{array}{l}\text { Process / } \\
\text { the } \\
\text { organisation } \\
\text { as a whole }\end{array}$ & $\begin{array}{l}\text { - Embedded security- } \\
\text { features } \\
\text { exploitation } \\
\text { - Audit } \\
\text { - Process assurance } \\
\text { - Standard } \\
\text { compliance } \\
\text { - Contractual } \\
\text { assurance } \\
\text { - Insurance } \\
\end{array}$ & Shelter & $\begin{array}{l}\text { Dhillon \& } \\
\text { Moores, } \\
2001 \\
\text { Liechtenstein, } \\
1996, \\
\text { Spurling, } \\
1995\end{array}$ \\
\hline Societal & $\begin{array}{l}\text { Primarily } \\
\text { component- } \\
\text { based (multi- } \\
\text { application) }\end{array}$ & $\begin{array}{l}\text { Stakeholder / } \\
\text { System }\end{array}$ & $\begin{array}{l}\text { - Responsibilities } \\
\text { definitions in } \\
\text { job descriptions } \\
\text { - Education } \\
\text { - Training } \\
\text { - Ethics } \\
\text { - Legal framework }\end{array}$ & Web & $\begin{array}{l}\text { Spinellis } \\
\text { et al., } \\
1999, \\
\text { Muir, } \\
1997\end{array}$ \\
\hline
\end{tabular}

\section{CONCLUSIONS}

There are currently very few disciplined approaches to integrate security with systems implementation, mainly because there seems to be a lack of understanding that it is a problem to be faced from a problem-solving perspective and not as a traditional IT security problem (Anderson, 1993; Hitchings, 1995a; Yngström, 1996).

It is not easy for an implementer or a user to have such an expert knowledge of the particulars of the available security practices/tools, so as to choose the most appropriate ones for a system under development. Therefore, there is a need for a mechanism to indicate the most appropriate security practices and tools per case. The framework we present in this paper provides reasoning to investigate the suitability of security tools within a given organisational environment and a development practice in mind. 
Security within IS comes through discourse and final agreement on what is important for the system, within which operations, what risks are there for the system and for its stakeholders. Thus, we believe that our approach is contributory to a new, more 'natural' view of IS security within organisations. Such a view is required so as to reveal the real social and organisational related character of IS security that nowadays seems to be locked behind the technicalities of the field.

We adopted the use of metaphors in order to stimulate the reader to reexamine assumptions underlying security, by imagining different combinations of organisational and development variables. IS security can be perceived in terms of required system states and fall under imagery descriptions. Each one of those descriptions signifies a different area of applicability and is based on different key-concepts, implying a different security approach and hence tools that are suitable for it.

Such use of metaphors is particularly recommended for interpretivebased IS intensive research (Walsham, 1991). However, we know that such an approach undergoes inefficiencies, as metaphor-based analogies can provide mind-trapping 'explanations of the world' (Boland, 1989). Used though as an analytical tool and a rough guide, we believe that they can significantly contribute to the implementation of secure information systems.

\section{REFERENCES}

Anderson, R.J. (1993), "Why cryptosystems fail", Communications of the ACM, Vol. 37, No 11 , pp. 32-44.

Backhouse, J. and Dhillon, G. (1996), "Structures of responsibilities and security of information systems", European Journal of Information Systems, Vol. 5, No 1, pp. 2-10.

Baskerville, R. (1993), "Information Systems Security Design Methods: Implications for Information Systems Development”, ACM Computing Surveys, Vol. 25, No. 4, pp. 375414.

Boland, R.J. (1989), "Metaphorical traps in developing information systems for human progress", in Klein, H.K. and Kumar, K. (Eds.), Systems Development for Human Progress, Elsevier Science Publishers, pp.277-290.

Chadwick, D.W. and Basden, A. (2001), "Evaluating Trust in a Public Key Certification Authority", Computers \& Security, Vol. 20, No 7, pp. 592-611.

Dhillon, G. and Moores, S. (2001), "Computer crimes: theorizing about the enemy within", Computers \& Security, Vol. 20, No 8, pp. 715-723.

Eloff, M., and Von Solms, B. (2000), "Information Security: Process Evaluation and Product Evaluation”, in Qing, S. and Eloff, J. (Eds.), Information Security for Global Information Infrastructures, Kluwer Academic Publishers, pp. 11-19.

Finne, T. (1998), "A conceptual framework for information security management", Computers \& Security, Vol 17, pp. 303-307.

Fitzgerald, B. (1998), "An empirical investigation into the adoption of systems development methodologies", Information \& Management, Vol. 34, pp. 317-328. 
Frosdick, S. and Odell, A. (1996), "Practical management of programme risk: the case of the National Strategy for Police Information Systems for England and Wales", Information Management \& Computer Security, Vol. 4, No 5, pp. 24-33.

Hitchings. J. (1995a), "Deficiencies of the traditional approach to information security and the requirements for a new methodology", Computers \& Security, Vol. 14, pp. 377-83.

Hitchings, J. (1995b), "Achieving an Integrated Design: The Way Forward for Information Security", in Eloff, J. and von Solms, S. (Eds.), Information Security - the next decade, Chapman \& Hall, pp. 369-383.

Liechtenstein, S. (1996), "Factors in the selection of a risk assessment method", Information Management \& Computer Security, Vol. 4, No 4, pp. 20-25.

Morgan, G. (1997), Images of Organization, 2nd Ed., SAGE Publications, California.

Muir, S. (1997), "After the break-in occurs: How to handle the student hacker", Library High Tech, Vol. 15, No 1\&2, pp. 92-95.

Siponen, M. (2001), "An Analysis of the Recent IS Security Development Approaches: Descriptive and Prescriptive Implications", in Dhillon, G. (Ed.), Information Security Management: Global Challenges in the New Millennium, Idea Group Publishing, pp. 101124.

Siponen, M. and Baskerville, R. (2001), "A New Paradigm for Adding Security Into IS Development Methods", in Eloff, J.H.P. et al. (Eds.), Advances in Information Security Management \& Small Systems Security, Kluwer Academic Publishers.

Smith, E. and Eloff, J.H.P. (2001), "Transaction Based Risk Analysis - Using Cognitive Fuzzy Techniques", in Eloff, J.H.P. et al. (Eds.), Advances in Information Security Management \& Small Systems Security, Kluwer Academic Publishers.

Spinellis, D., Kokolakis, S. and Gritzalis, S. (1999), "Security requirements, risks, and recommendations for small enterprise and home-office environments", Information Management \& Computer Security, Vol. 7, No 3, pp.121-128.

Spurling, P. (1995), "Promoting security awareness and commitment", Information Management \& Computer Security, Vol. 3, No 2, pp. 20-26.

Tryfonas, T. and Kiountouzis, E. (2002), "IS security and the IS development project: Towards a framework for their integration", in Ghonaimy, M. et al. (Eds.), Security in the Information Society: Visions and Perspectives, Kluwer Academic Publishers, pp. 347-356.

Walsham, G. (1991), "Organisational metaphors and information systems research", European Journal of Information Systems, Vol. 1, No. 2, pp. 83-94.

Walsham, G. (1995), "Interpretive case studies in IS research: nature and method", European Journal of Information Systems, Vol. 4, pp. 74-81.

Wood, C.C. and Snow, K. (1995), "ISO 9000 and Information Security", Computers \& Security, Vol. 14, pp. 287-288.

Yngström, L. (1996), "A holistic approach to IT security”, in Eloff, J. and von Solms, S. (Eds.), Information Security - The Next Decade, Chapman \& Hall, London. 